\title{
KEREMCITA: SPEECH RELATIONS AND SOCIAL RELATIONS IN HIGHLAND CHIAPAS
}

\author{
John B. Haviland \\ Australian National University
}

Revised draft of paper presented to the Symposium on Language in Cultural Context, joint session of meetings of the Australian Anthropological Association and the Australian Linguistics Society, 27/8/81. To appear possibly in projected Working group volume "Culture and Conversation".

\section{Speech relations and social relations}

The thesis of this paper is simple, unexceptionable, and largely obvious. I hope to save embarassment, thot my reader swill already subscribe to it implicitly, so that I will not need to argue for it so much as demonstrate it, in the context of relations between Tzotzil speaking Zinacanteco Indians of highland Chiapas, and Spanish speaking ladinos in the same region. There is clearly a relationship between the social organization of an aggregate of people and the organization of speech in the corresponding community. I want to make the seemingly stronger claim that what I will term "speech relations" and social relations more generally are, in an experimental sense at least, virtually co-extensive; that social life is played out and constituted centrally by language interaction. (This is very much like an argument made eloquently and persuasively in a recent paper by Michael Moerman [1981]. My version, coming from a different lineage, is somewhat cruder, I fear, and also more political. People do, after all, have to live with the speech/social relations they find themselves enmeshed in. Our ethnographic tidbits run the risk of so disembodying our subjects that we forget the real lives they live.) 
If the thesis is true it has obvious and inescapable ramifications for studies of both language and society.

People inhabit a world that is, typically, only partly accesible to them. Inescapable constraints of power and economics, of control of production and access to resources, circumscribe and configure the realm of social life, in which people relate to one another, talk, eat, joke, work, and love. Our contact with harder less tractable "material preconditions", is ordinarily mediated through the interactions we have, face to face, with one another; this is the level at which social organization becomes sociability, or at which the "social relations of production" become part of our social lives. When people talk, they use forms of language that have themselves been shaped by the winds of history; they come together in circumstances, and with purposes, whose parameters are set by material facts. Their speech, then, is subject to the same sorts of constraints as, in this crudely sketched view, are other facets of their lives. Talking together, however, is one primary means by which people establish and maintain a relationship, or change it. In this sense, given whatever primary constraints there may be on a social form, language is both reflective and constitutive of social relationships. My thesis connects the features of interaction through speech - the resources it uses, the circumstances under which it occurs, and so on - with the resulting social order.

The thesis actually involves a set of interrelated but distinct propositions, corresponding to different realms of the analysis of social life. First, it involves the claim that natives' culutral understandings typically connect language intimately with social life and sociability. (It is on the basis of an appeal to our own cultural understandings that I say I expect general agreement on the thesis). Second, the thesis suggests that social relations unfold, and social organization is constituted, conceptually at least, predominantly in the realm of acts of speaking; that there is, in any case, an elaborate cybernetic feedback relationship between the relations of speech and developing social relations. Finally the thesis predicts that both social relations and speech relations are, on a more perspicacious analysis, themselves epiphenomenal, or dependent functions of other independent constraints on human life, then both dance to the same tunes. If, for example, there is an asymmetry in access to productive resources between two interacting groups of people, or a change in the balance of such access over time, then the asymmetry will be reflected 
similarly in both their social relations and in the language they use with one another.

I will start with a brief historical view of the area of southeastern Mexico I am concerned with, and I will provide some numbers relevant to Spanish, Tzotzil and bilingualism in Chiapas. Then rather than argue for the thesis, I will illustrate it with a series of ethnographic vignettes that deal with a gradually widening set of concentric social circles, from a small Indian hamlet outwards. I will show that the thesis allows bi-directional inferences about its two terms. Much of my ethnographic material is drawn from impressions on a recent brief visit to the municipality of Zinacantán, where I have been working over the past fifteen years.

\section{The setting}

According to the 1970 Mexican national Census (the most recent available in Australia unfortunately), out of a total population of just over one million, of whom 590 thousand are literate, the Indian population of Chiapas was about 288 thousand. 140 thousand were shown as 'knowing Spanish'. This leaves more than half - about 148 thousand people - listed as monolingual speakers of Tzotzil, Tzeltal, Chol, Tojolabal or one of the other less numerous Indian languages spoken in the state. The Census showed 50 thousand monolingual Tzotzil speakers and another 45 thousand who also spoke Spanish.

For Zinacantán, one of the 21 municipios in which Tzotzil is spoken by a significant portion of the population, the 1970 figures were as follows: 4,662 monolingual speakers of Tzotzil, and another 3,741 who also spoke Spanish. The breakdown by sex is somewhat more revealing, showing men as bilingual in more than half the cases, but women only rarely bilingual - a feature all the more striking when compared with similar figures from the 1960 Census. Census figures on such matters are notoriously dubious, however, and it is hard to know what criteria were applied, in communities like Zinacantán where the very schoolteachers who were charged with teaching Spanish were themselves the, perhaps overly self-congratulatory, Census takers.

It is difficult to gauge more recent trends, but in Nabenchauk, the small paraje where we have worked most intensively, the population since 1970 has grown from about 800 to well over 1400 
people, and virtually every man between about 5 and 25 now speaks at least some Spanish, whereas it still seems rare to find girls out of their teens who will (willingly) do so.

Official policy regarding Indian languages has had a checkered and cyclical history in Mexico, as Shirley Brice Heath has documented (Heath 1972). The invading Spanish Conquerors, and their Colonial successors, were quick, to recruit a class of interpreters (called Naguatlatos) who were the original brokers of Indian-Spanish relations. Crown policy, according to Heath's resume, was from the beginning ambivalent about the relationship between different linguistic varieties and possibly competing goals: Spanish was the language of the Empire, required to control the new subjects; but vernaculars were necessary and effective instruments of conversion. (Heath 1972: 67).

In this century there have been, again, two competing philosophies vying with each other, each with cyclical periods of ascendancy. In 1911, for example, the platform of the Partido Popular Evolucionista included a plea for expanded teaching of Spanish, both spoken and written, especially among Indians, following the suggestions of the influential conservative educator Gregorio Torres Quintero, who wrote in 1913 that teaching Indians in their native tongues would help to preserve them, something that would be "very nice for linguistics and antequarians" but a "very considerable obstacle to civilization and the formation of a national soul." (1913:3-4) Torres Quintero foresaw that Indian languages would simply wither and die if all education was in Spanish. Similarly, José Vasconcelos, an influential Hispanic scholar in the Obregón era around 1921, recommended the elimination of "la personalidad india" through a thoroughgoing hispanization of Indian education, and an elevation of Indian souls by teaching them the great classics - Dante, Homer, Tolstoy - which he caused to be disseminated in Spanish among illiterate Indian peasants around the countryside (Heath 1972: 136).

By contrast, during the reforms of the 1930s, the Cárdenas administration formed the first Indian Affairs agency, and fomented bilingual programs to combat the massive illiteracy rate (at least $78 \%$ in Chiapas at that time according to Heath 1972:161-2). Language policy was influenced by a new concern for native languages, for cultural multiplicity, and even by somewhat cynical Stalinist ideas about preserving native languages as effective means of education and development. (See E. Glyn Lewis 1972.) The famous Tarascan 
Project of 1940, in which Tarascan Indians learned to read and write, first in Tarascan and then in Spanish, gave "undeniable proof" of the success of the bilingual method (Heath 1972:176).

There has been a bewildering cycle of fashions and philosophies in the area of Chiapas where I work, so that within the same community there can exist, side-by-side, schools directed and staffed by local Indianist agencies, with native Tzotzil speaking Indian teachers (specially recruited and trained as promotores culturales), and, as in Nabenchauk, other government schools which use a dogged 'direct method' (in which teachers are monolingual in Spanish, and pupils monolingual in their own language!). Even as recently as April this year, a Nabenchauk schoolteacher asked me whether the 'dialect' spoken in the village was Tzotzil or Tzeltal, and whether it had ' $a$ grammar'. (He didn't mean a book on grammar, either.) And just as Vasconcelos wanted to elevate the Indian soul through teaching the classics, an influential Chiapas educator published, in 1974, a tract on the theory and practice of education, in which he argues, in explicit reference to the Indian population of Chiapas, that only through education can one "elevate man, sublimate his animal nature through intellectual, moral and artistic formation". He goes on to assert that only through education in Spanish can we succeed in "incorporating into Chiapas 600,000 brains that up to the present remain inactive" (Weber 1974: 31).

The specific history of Zinacantán has brought about more sweeping changes in the linguistic profile of the community than any system of education. Before the Mexican Revolution, Zinacantán consisted of a set of small, isolated communities, hemmed in by large ladino (non-Indian) fincas. The Zinacantecos raised corn on their own highland fields, and engaged extensively in trade and transport, traditionally selling salt throughout the highlands, and running mule trains with a variety of ladino owned goods. The revolution brought back into the community a great mass of former Indian peons who were driven from the large haciendas of the lowlands. Later land reform, and revised strategies by non-Indian landowners to procure Indian labor on their properties, resulted in a shift away from trading to massive lowland rental of cornfield land, and group or family sharecropping. It was only since the thirties and forties that Zinacantecos could afford the luxury of conducting their commercial lives largely in Tzotzil (working in independently organized Indian farming teams). Before, Zinacanteco muleteers learned a good deal 
more Spanish in the course of their commercial lives than their more provincial sons were subsequently required to do. (In the family that we know best, for example, the 60 year old head of household knows almost no Spanish, unlike both his 90 year-old father, who speaks fluent broken Spanish, and also unlike his own sons, who have learned Spanish in school, and working casually as wage-laborers.)

Formerly, also, the management of Indians for non-Indian (ladino) purposes was largely in the hands of ladino specialists. Those people who spoke both Tzotzil and Spanish were the non-Indian brokers of Indian goods and services: the enganchadores (literally 'hookers' who recruited and entrapped highland Indian laborers for the lowland coffee fincas - a system dramatically, and evidently accurately portrayed by B. Traven in the Rebellion of the Hanged; or the atajadoras (literally 'interceptresses'), predatory women who line the roads and trails coming into commercial centers like San Cristóbal, cutting off Indian primary producers and parting them from their produce, in order to resell it themselves. (See Rus 1975.)

In Zinacantán the few competent Spanish-speakers over thirty years old virtually all acquired their linguistic skills (and considerable expertise in the ways of non-Indians as well) during periods as semiadopted child servants in ladino households. (See, for example, Pozas 1952, Moriano 1968, Freeman 1974.) Such children were usually identured to ladino families by impoverished Indian families, becoming what are called in Tzotzil kriyala (Spanish criada or criado 'raised-one'), or more descriptively $j$-prental (from Spanish prendar 'pawn'). Although some of these people remain somewhat marginal members of their communities, neither Indian nor ladino, many, both men and women, have parlayed their skills into positions of some power and influence as mediators between their Zinacanteco fellows and ladino institutions, particularly the civil authorities. (These are the so-called 'Zinacanteco lawyers', as well as many recent municipal civil authorities, who were chosen by outside political forces because of their abilities in Spanish.)

\section{The linguistic varieties}

The standard view of a language situation like that of highland Chiapas, and reflected in the statements of policymakers like those noted already, first atomizes the varieties, and second, considerably 
oversimplifies the distribution of varieties within individual repertoires in a population. Policy recognizes only Spanish and vernacular (something like the division of language varieties, in most parts of Australia, into English and 'lingo' or 'language' - the latter referring to any Aboriginal language); whereas, there are, of course, not only many different Indian 'dialects' spread over several languages in dictinct communities, but also diverse varieties of Spanish, and a range of differentially distributed registers on both sides. I need say nothing about the range of Spanish varieties spoken by such disparate groups as the wealthy peolple from Mexico City, or the isolated farmers on their backwoods haciendas, or the poor illiterate slum dwellers of the San Cristóbal fringes. Even within a small community like Zinacantán, however, as my colleagues in the Chiapas project have documented at some length elsewhere, the range of distinguishable varieties of Tzotzil covers rather wide ground. In addition to the geographically indexing dialectal variants, there are also special 'ritual' varieties (characterized by parallel couplet structure) which are appropriate to k'ak'al k'op 'heated speech', prayer, 'baby talk', and so on.

There is also considerable mixing of varieties (mixing which clearly has gone on for all of the 400 years since the Conquest, judiging by the various stages of Tzotzilization we observe in different loans). Such mixing is, of course, evidence that the social organization of this highland region must be considered as a single, though complex, 'speech community', rather than, say, a cluster of distinct but interconnected communities.

Anticipating slightly my later observations, I should point out that the distribution of varieties, and the features of mixed varieties, are characteristically asymmetric. Indians talk up, trotting out the best and most polite Spanish they can muster in talk with ladinos. Zinacantecos are, in fact, masters of alter-aggrandizing and self-belittling in their often rudimentary Spanish. I have heard a Zinacanteco give a ladino lawyer the triple whammy, addressing him as "Señor Licenciado Don Chus", with three deferential titles included. By contrast, some ladino acquaintances recently told me scornfully about a hapless Chamula man who comes day after day to a government office to declare "Quiero uno mi trabajito" - not only syntactically nonsteandard, but plaintively diminutive. (The possessive pronoun is out of place in proper Spanish, but totally obligatory in the corresponding Tzotzil sentence.) 
Rodolfo Stavenhagen, commenting on the ladino control of the commerce in foodstuffs in the area, points out that

These various forms of exploitation of which the victim is the Indian merchant, in his capacity as vendor and buyer, are due to the economic and political control of the ladinos of the city. This power is reinforced by a cultural superiority which is manifest in their acquaintance with the mechanisms of the formation of prices, with the laws of the country, and above all with the Spanish language, the ignorance of which on the part of the Indians is yet another feature of inferiority and social opression. (Las clases sociales en las sociedades agrarias, 1969:225, my translation.)

Not only do ladinos know more and better Sapinsh than local Indians in general do, they talk down. I have heard a ladino nurse utter a sentence which is pragmatically self-contradictory (in much the same way that Judit Irvine's example is pragmatically ironic judge's wife to judge: "Will your Honor be so kind as to take out the (Goddamned) garbage..."). Speaking to the local magistrate, the highest hamlet official, she asked:

¿Tú eres el agente municipal?

Are you the municipal agente?

The contradiction comes, of course, from the juxtaposition of her addressee's title, a position canonically requiring, at least in a public setting, a certain formal deference, and the second person singular pronoun, the $\mathrm{T}$ form in Spanish.

A similar explanation lies behind my title. Indians are, routinely and regardless of age, muchachos and muchachas (boys and girls) to the ladinos with whom they ordinarily deal in the towns. Since many ladinos know smatterings of commercial Tzotzil (and a few considerably more than that), some also lace their talking down with bits of Tzotzil. Hence, my friend Jan Rus has told me of hearing a ladino re-seller of vegetables address a Chamula woman, whom she was trying to procure cabbages or radishes, as keremcita, a semantically odd neologism composed of the Tzotzil root kerem 'boy', plus the phonologically appropriate feminine Spanish diminutive suffix, vielding "little female boy".

\section{The innermost circle: language in Zinacanteco social life}

A number of authors have examined two central Tzotzil words for speech, $k^{\prime} \circ p$ and $l o 7 i l$, in order to argue that language is central 
to Zinacanteco conceptions of the social order. $K$ 'op means 'word, language' but also refers to any affair, argument, dispute, or serious matter. Lo7il means 'speech', or 'conversation', and represents the canonical informal social interaction. I will not repeat the various taxonomies of speech, which are familiar from the literature. Instead let me offer some observations about Zinacanteco conceptions of speech and society.

(a) Just being human means being able to talk. The exceptional case is first: going to visit a kinsman after a three-year absence I was grilled by his neighbors in characteristic Zinacanteco prying fashion. I was subjected to a fifteen minute barrage of questions (all in Tzotzil), about where I was from, where I was staying, how long I was there, etc., etc. - and the last question was: "Do you speak Tzotzil?" - here interpretable not as a genuine request for information, but as a desire to confirm and ratify my genuine humanity. Zinacantecos, in town, seem often just not to see, not to recognize as social alters, non-Indians, especially non-Zinacantecos; the immediate social universe is the universe that can be talked to. A speech disability is tantamount in Zinacantán to a mental defect: one of my goddaughters is big for her age, and, as her parents tell me apologetically every time I am reacquainted with her, she is still chich; this means literally that she either doesn't talk or talks foolishly, but it implies that she is simple-minded and immature.

(b) Ordinary sociability and friendliness, as well as most effective social actions are not only carried on largely in words in Zinacantán, but are also denoted by expressions that make explicit reference to talk. Visiting, asking favors, making formal requests - all are instances of $k^{\prime}$ opon-ing or talking to someone. If one doubts ones own abilities one adquires a mouthpieces, a $j$ - $k$ 'opojel, to do the talking. (Formal ritual events of all kinds have special authoritative talkers, and even a shaman, in Zinacantán, is a kind of hired specialist talker, whose skills are evaluated in terms of how well he or she 'talks', i.e., prays.)

Conversely, anger, enmity, and contention are characteristically conceived of as absences of or breakdowns in talk. When arrangements for a wedding in our house compound were, this past April, continually being sabotaged by one crisis after another, my old compadre put his head in his hands and said

K'u ma yu7un naka soktesokte li k'ope?

"Why is the word always being spoiled?" 
using an affective verb meaning 'ruining itself all over the place' or 'walking around getting spoiled', to describe the k'op - the word, or, here, the affair. Relatives who have fought, broken off relations, mu xa sk'opon sbaik: no longer talk to one another. The silence can go still deeper: one of my oldest compadres has fought bitterly with his eldest son, and he no longer can bring himself to utter that son's name, referring to him instead by an ironic but underspecified euphemism: jtatatik ta jech 'our grandfather across the way'. And when a fight is finally settled, it is done so, whether at the town hall or before elder kinsmen, ta lekil k'op 'with good words'.

(c) Zinacantán is small enough that one is likely to know almost everyone who lives in the same hamlet, and to know by sight many people from other villages as well. Moreover, since Indians in the Chiapas highlands usually wear at least some part of their dictinctive local costume, they carry their ethnic allegiances on their backs. Even on the crowded streets of San Cristóbal, unacquainted Zinacantecos will often greet each other with the verbal formulas of a tiny interaction. To say, to another Zinacanteco, chibat "I'm going", and to receive the appropriate response, batan "Go!," is to establish, acknowledge, and immediately abandon, the minimal social relationship: the recognition of another as social being. Zinacantecos extend the same courtesy to other highland Indians in chance encounters on the path; reciprocal address terms between whole municipios provide a standard greeting which similarly acknowledges mutually recognized social co-presence. Zinacantecos and Chamulas address each other with the term ulo7 ('visitor', from yul-'arrive'), even in absolutely minimal greetings. Zinacantecos and Ixtapanecos have the reciprocal term amiko 'friend'; and even with Indians from Tenejapa, who speak Tzeltal rather than Tzotzil, Zinacantecos use and receive the term molol (related perhaps to mol 'elder man').

When Zinacantecos venture farther from home, however, they often shed their brightly colored red and white cotton garments in favor of the anonymous garb of rural peasants. Nonetheless, their ears remain pricked, attuned to the familiar words of batz' $i k^{\prime} \circ p$ 'the real language'. I have been on a bus so crowded that chickens were stored on the luggage racks, and children crouched under seats, when the din of diesel engine drowned out nearly all talk, Spanish or otherwise, only to find that my Zinacanteco companions have eavesdropped in detail on the Tzotzil conversations of other Indians. Speaking the real language, in such otherwise strange surroundings, 
constitutes a special claim to personhood, and seems to allow people to interact immediately, without introduction or preliminary. (Reversing what would seem a normal progression, I have seen a $\mathrm{Zi}$ nacanteco break directly into a Tzotzil discussion by unknown Zinacantecos, asking about details of the land and crops being discussed, and only later proceeding to introductions and identifications.) Here language provides both the license and the medium for establishing social interaction.

(d) It is through words that Zinacantecos reach the very limits of the acceptable social world. Illicit sexual liasons (an issue that was part of the marriage affair's walking around spoiling itself) are examples of k'opon-bail 'talking together' - a youth can be dragged into a shotgun wedding for 'talking to a girl in secret'. Similarly in reverse: 'talks to boys' is a euphemism for the loko zeb 'promiscuous, loose girl'.

Socially framed hostility takes a characteristic spoken form as well. Tzotzil has a plentiful supply of words meaning 'mock, scorn, sharie, make fun of... verbally'. (Labanel 'libel, slander' is, of course, prosecutable and $T$ know a man who dragged his father-in-law into court and got a cash settlement because the older man had muttered some critical, though as it turned out unfounded, remarks.) Anger and disputation themselves take a characteristic verbal form, and heated denunciation or scolding will often be expressed in parallel couplets akin to the highly structured language of prayer and song (see Haviland 1982).

Standardized joking routines, in which people try to top one another with elaborate word-play, usually aimed at a particular victim, also sonetimes turns serious. The hamlet where we work is split into two bitterly, often violently opposed political factions. I observed a lone man from one of the factions, somewhat drunk, subjected to a merciless verbal pounding by a large group from the other faction in one of these half-serious joking encounters. Shortly before passing into a drunken stupor, the man stood up and declaimed: 'Hah! Who says that I can't answer lo7il - where lo7il means 'talk' or 'conversation', referring to the stylized joking interaction, here turned agressive and nasty.

(e) Talking is also a dangerous breach in the wall of confidentiality that Zinacantecos like other peasants, try to erect around their private lives. (Leslie Haviland and I have written on the privacy of Zinacanteco households elsewhere [forthcoming].) Not only can people overhear what one says, so that barriers are necessary and 
precautions must be taken, but all conversation outside one's household is potentialy dangerous. One precaution, when conversation on the outside is inevitable (when, for example, someone is being sent on an errand), is to issue precise instructions about what to say, to whom, and what words to use. When our errant groom-to-be was running from the law, recently, we were all told, around the fire, exactly what lie to disseminate about his whereabouts, should we be asked. The reverse process is also dangerous: when people say things to you, there is a constant possibility of cho7el, literally 'peeling', i.e., 'trickery'. When, before this same ill-starred wedding, a local official said to one of the groom's brothers 'Everything is all right, go ahead with the marriage", the entire household was sent into a panic, trying to figure out what mischief the official really had in mind.

\section{Speech relations at the boundary}

Talk, then, has a central place both in the internal cultural view and in the day-to-day social practices of Zinacantecos. Wider social relations, dealings with non-Zinacantecos - similarly cotidian in modern Chiapas, but with a somewhat different character - are also enacted through a verbal medium. The resources of speech available therefore enter into what I called earlier a feedback relationship with the resulting social forms. Again, I will limit myself to a few examples.

(a) external relation to exert internal pressures.

Just as domestic quarrels require verbal settlement (settling a fight is, in fact, called meltzan k'op 'to fix/make words', and 'to pick a fight' is to $s a 7 k^{\prime} \circ p$ 'search for words'), bigger fights require more potent talkers. It has long been an evil Zinacanteco ploy to make trouble for your enemies by instituting legal proceedings against them, on whatever frabricated charges possible, in the ladino court system. Whatever the outcome and whatever the issue, one result is guaranteed: the costs and inconvenience of a legal wrangle will considerably put your enemy out (you as well, unfortunately). The strategy has created a market for the Zinacanteco 'lawyers' I mentioned earlier: people whose knowledge of Spanish makes them indispensable allies in any dispute that requires fluent and persuasive Spanish. 
Such people are viewed with considerable unease. In the Who's Who of Zinacantán I compiled some years ago, the description sna7 kastiya 'knows Spanish' was consistently linked with the characterization $j s a 7-k^{\prime} \circ p$ 'troublemaker'. (And one of my favorite nicknames is jtubtavanej 'spitter', applied to one of these Zinacanteco lawyers whose everyday speech is said to be an almost incomprehensible mixture of Tzotzil, Spanish, and spit.)

Recent legal disputes between the two dominant political factions in the community have been particularly bitter. The ordinary man lives in fear of having to pay gigantic legal costs (to hire these and genuine ladino lawyers) and to face extremely difficult Spanish interrogation. Ulitmately the most talented talker seems to carry the day. I have spent some time studying the transcript of a long session before the director of a local Indianist development agency, himself a lawyer with considerable power in Zinacantan, in which my compadre made a complaint against the local civil authorities for cutting down some of his milpa and fruit trees to build a road. Although my compadre is a respected pasaro, a man who has completed a distinguished career in the religious hierarchy, a totilme 7 il, a 'father-mother' or ritual advisor, and also the senior ch'ul mol or 'Holy Elder' responsible for Easter rituals, in such instrumentally important dealing with ladino officials, with the Nabenchauk political mafia against him keeping up a constant Spanish din, he might as well have been mute.

\section{(b) hilarious literacy}

Another feature of Zinacanteco political life has been the place of the Spanish written word. For many decades the most direct avenue of control over Indian communities by the outside ladino world was through the municipal communities were Indians, at least in principle elected by the communities involved, the secretary has traditionally been a ladino - often the single ladino resident in town. (Another B. Traven novel, called Gobierno, describes the life of such a ladino secretary during the Porfiriato, before the Revolution.) His was the job of keeping records in Spanish, and, importantly, creating the actas, the legal documents specifying the terms of legal settlements. (Nearly every Zinacanteco house some. where has a chest in which may be found a few worn, yellowed, carefully folded sheets of paper, which no one can read, but which seem to be important enough to keep.) When documents are keys 
to action outside the community, the master of the written words is a powerful gatekeeper.

One widely distributed literacy skill is the ability to write one's own name, or at least to sign with the Spanish system of patronym and matronym. What renders the skill of dubious value is the fact that the Spanish system of names fails to identify people: so many people in a hamlet like Nabenchauk have the same Spanish name, that many hours are spent poring over lists of names trying to figure out exactly which Manuel Pérez Pérez this one might be. The ordinary Tzotzil system, combining double patronyms with periphrastic nicknames, is much more successful, but Tzotzil names are not ordinarily written.)

Zinacantecos are becoming more literate, and the creation of new skills has produced new dangers. During the troubled sourse of the wedding I have mentioned, much was made of the fact that the bride-to-be sna7 vun 'knew paper' - that is, could read and write. When she threatened to call off the marriage (because she had heard that her intended husband had publicly slandered her), the great fear was that she would go herself to the priest, to ruin the arrangements already made.

Literacy also produces new possibilities for harassment. To be married in Zinacantán now requires that the bride and groom produce written evidence to prove that they have learned the catechism. (In the old days, according to my compadre, it was easier. if you didn't marry in church no one worried about catechism, and if you did marry and could not properly answer the priest, he would only beat you.) The rule was evidently instituted not by the church, but by the political faction that includes within its ranks all the literate church sacristans, whose signature must appear on the boletos attesting attendance at catechism classes. Members of the other faction are thereby endowed with an added annoyance if they want their children to marry in the church.

\section{(c) Middlemen}

Zinacantecos are caught up in a web of cornmercial dealings with the wider state and Mexican economy that largely define their lives. Life is work. In our household, everyone schedules his or her activities with the dogged persistence of a workaholic executive: up before dawn to cook, or to start the walk or catch the truck that will land one at one's workplace, with a day segmented into discrete 
and continuous tasks that leave no room for 'play' - something that children do. The commercial possibilities have always involved a ladino component, although it has been desirable to hold direct interactions with non-Indians to a minimum.

Cornfarming, for example, used to be organized among small groups of kinsmen, who together rented from a single lowland ladino landowner, usually one with whom they had established long-standing relationships, and who lived on the edges of the Grijalva within a day's walk from villages like Nabenchauk. Often these landowners, or their resident managers, were reasonably fluent in Tzotzil, having dealt with these same Indians over several generations. In any case, a single linguistically sophisticated Zinacanteco usually took over the negotiations about rent and the allocation of land, acting as spokesman for his farming group. And when Zinacantecos needed, in turn, to hire laborers for corn work, they hiked off to Chamula, a neighboring Tzotzil community, again to activate old contacts.

Nowadays, even cornfarming takes Zinacantecos farther afield, both geographically and socially. As population has grown, as corn land near the lowland borders of Zinacantán has become exhausted and tired, and as roads have pushed farther and farther into the lowland hinterlands, Zinacantecos have started moving their corn operations farther from home.

My compadre's cornfields now lie a full days' truck and bus ride away from Nabenchauk, with a four hour walk at the end of it. His landlords are now ladinos who, until recently, would hardly have seen a Zinacanteco, let alone learned rudimentary Tzotzil as children playing with sharecroppers' kids. Now, the man in charge of organizing the farming operation in which men in our household compound participate is, in fact, himself one of a very small group of ladinos who live in Zinacantán, completely bilingual in Tzotzil and campesino Spanish. When we went, near the end of April, to burn off the felled trees and brush on this year's fields, it was this linguistically talented spokesman who not only organized commercial matters with the landlord and his sons, but who also kept relationships cordial: being sure to call on the grown sons and daughters of the landlord, to drink with them, to offer (not without some explicit private calculations of costs and possible benefits) his and his Zinacanteco partners' help to the landlord on his own farming operations. My compadre himself must remain a dumb appendage 
to such interactions, and it is only his sons - and in particular his youngest, somewhat obstreperous but clever son - who can begin to negotiate these more complex linguistic paths without Mario as middleman.

(Another strategy for acquiring corn land has been, in recent years, to try to force government application of land reform provisions to establish new ejido colonies on Federal land in Hot Country. Again, considerable linguistic and political expertise is required, and the only such movements that have succeeded have depended entirely on the persistent and persuasive abilities of one of the talented Zinacanteco 'mouthpieces' of the sort I mentioned before: men who acquired fluent Spanish during extended periods among ladinos as children.)

Let me mention one further commercial example. In Nabenchauk there is a small group of men who make their living without any corn farming. They are flower-sellers, who grow a certain amount of flowers (and vegetables) to sell in ladino markets, but who largely resell the produce of other highland Indians, transporting their weekly 7ikatzil 'burdens' to lowland, even Coastal, towns. Such men need to know enough Spanish to bargain (as vendors, though) in the market, to deal with the market and government bureaucracies (for example, to pay the various fees for reserving a bit of space at the market, or the bribes required by the fiscales, the inspectors of produce trucks on the highways). But again the business, when I did a bit of flower selling five years ago, was carefully organized to minimise dealings with non-Indians. The bulk of one's cargo was bought from other Tzotzil-speakers: I bought carnations from Indian women from San Felipe, radishes and carrots from Chamulas in the San Cristóbal market. The flowers were transported to the lowlands on a Zinacanteco truck, retained every week for this job, and whose owner and driver had been carefully made a compadre by all the regular flower-sellers.

The whole business has taken an astounding new turn. A few Zinacantecos still make their entire livings selling flowers, and they still have weekly runs between the Tzotzil highland and the lowland markets where each idividually has established his retail outlet. But the scale has grown incredibly. Certain Zinacantecos now make weekly or fortnightly trips from Zinacantán to the Mercado Jamaica in Mexico City, a distance of over 1000 kilometres, or about twenty hours by open truck. They go to buy flowers, exotic varieties grown in Michoacán market gardens. Not surprisingly, the relationships have 
also charged somewhat. As the sociologist Everett Hughes has pointed out, contact between language groups may produce only rudimentary linguistic accommodation, but bargaining requires a richer language. These modern floral entrepreneurs must negotiate a path through a Spanish environment that knows nothing of Zinacantán, and that has hard not even a word of Tzotzil (just as the trucks that carry these flowers must negotiate some tricky Mexico City streets - each truck is equipped with a 'pilot' who has managed to memorize the ratrun that will bring the truck from the outskirts of the city directly to the Mercado Jamaica, and out again). The ranks of such Zinacanteco flower-barons now include a few of the old mob of Zinacanteco 'lawyers', but mostly comprise young men who have been to school, who are both fluent and literate in Spanish, and who have cultivated a facility with ladinos that is premised on working away from the Chiapas highlands, where the form of Indian/nonIndian relations is often fixed and unalterable. The ambiguity of these Indians' identities is reflected in their ways of talking, in their command of a wider range of Spanish registers and in a peppering of once unfamiliar Spanish words throughout even in their everyday Tzotzil conversation.

\section{(d) monopolies}

Other commercial possibilities involve monopolies on the resources made available by Government aid programs to Indians. What I have called the Nabenchauk "mafia" is a group of Zinacantecos who have become, largely through their control of Spanish, the officially recognized chanels of government funds into the community. When a new road is to built, ladino bureaucrats approach them. When a reforestation project is introduced, they are the ones who can hire workers. If someone wants to buy a truck, he must organize the paperwork, and negotiate his entry into the union of small transporters through the Mafia. Social relations, here, are mediated because communication between parties is also mediated. I can go to a local jmeltzanej-k'op, Zinacanteco style, with a bottle and a request. $\mathrm{He}$ can, if convinced, translate my desires (for a job, for a bit of legal clout, for a bit of persuasive talking) into the appropriate outside idiom.

(e) how does it feel?

Let me close with a few final observations. One of my flowerselling compadres, who spends the great bulk of his time away from 
Nabenchauk carrying on his negocio, talks continually about the places he visits. It is easy to see him energized and stimulated by the freedom of travelling through the countryside, Zinacanteco clothes stuffed into a plastic traveling bag, and his Tzotzil origins hidden behind a markedly Indian but otherwise anonymous Spanish.

One of the constraining bonds of social life in Zinacantán comes from a communicative powerlessness that renders still more oppressive economic and political powerlessnes. Zinacantecos in their native habitat wear the distinctive plumage of the Indian: if not the handwoven red pinstripe that sets Zinacantecos apart from all the other people of highland Chiapas, then at least the Tzotzil of their forebears. And the minute but constant reminders of subordination and powerlessness take the form of tiny interactions in which Indians typically lack the verbal armament to defend themselves, even if they had the opportunity and inclination to do so. Here are three final vignettes from my most recent trip to Zinacantán.

(i) In preparation for his wedding (which did, by the way, finally take place), my compadre's son Chep went to buy a large quantity of sugar, needed both for the special wedding foods, and for gifts to the families of bride and wedding godfather. After he bought some fifty kilos of sugar, the storekeeper announced the following rule: 'you can only buy sugar, if you buy a matching amount of soap.'

ii) On our way to the Hot Country cornfields, my compadre needed to travel for about six hours on a single bus. The only way to be sure of having a seat on these third class buses is to buy a ticket with a numbered seat designated. Since the bus was likely to be full, we arrived several hours early at the bus station, and tried to buy tickets. To the request 'Quiero boleto' my compadre was told 'No hay.' Yet, minutes before the bus was to leave, a large party of ladino women bought their tickets and took the last remaining seats.

(iii) Returning from the lowlands several parties of Indians gathered at a crossroad waiting to flag down a truck to carry them into the mountains. Several Indian owned trucks passed, full. Finally, one man approached a ladino heading in the right direction with an empty pickup truck. 'Are you going to San Cristóbal?' 'Yes.' 'May we ride with you?' 'Well, get on then, but hurry it up!' The ladino, in fact, packed as many Indians as he could on board, and started off 
He turned out to be a soldier from northern Mexico. But when it came time for people to get off, he demanded in payment about three times the normal cost of a truck ride. 'Pay me, pay me,' he shouted, 'you don't expect me to carry you for nothing, do you?' The Zinacantecos, without enough cash to pay what was demanded, stood silent. 'Well then, what's in this crate? Mangos? I'll take them instead.' More silence. Finally, some other Zinacantecos on the truck, thinking about what they would have to pay when their turns came, muttered in Tzotzil 'Run and borrow the money, fool, before he takes your chickens, too.'

People experience their social order through everyday encounters, whose medium is language. The tenor of these encounters, also expressed in language, sets the tenor of the relationships. In modern Chiapas, speech relations display an asymmetry that reflects a social, economic, and political asymmetry. Ladinos patronize, browbeat, and generally talk down to Indians in most of the situations I observed in April 1981, just as they have for 400 years. And, I may remark, the feeling is not entirely unreciprocated. Scrawled on a notice, dangling around the neck of Judas, as he hung from a rope above the church door at Easter, were the words mol kaxlan ta mejiko, which means "important ladino from Mexico City."

\section{REFERENCES CITED}

Freeman, W.

1974 The Lawyers of Zinancantan, Harvard College A. B. Honors Thesis.

Haviland, J., and L. Havilland

1983 "Behind the Fence The Social Bases of Privacy in Nabenchauk," Estudios de Cultura Maya, vol. XIV.

Heath, S.

1972 Telling Tongues, New York, Teachers College Press.

LEwIS, E. GLYN

1972 Multilingualism in the Soviet Unión: Aspects of Language Policy and its Implementation, The Hague, Mouton.

Modiano, N.

1968 "A Chamula Life," Natural History, january: 58-63.

Moerman, M.

1981 "Conversational Analysis and Ethnography: Finding Life in Dry

Pozas, R.

Dust," Working Group in Language in Cultural Context, ANU.

Rus, J.

1954 Juan the Chamula, University of California Press.

1975 'Indian Bilingualism in Three Periods," Typescript, Harvard University, Department of Anthopology. 
Stavenhagen, $\mathrm{R}$.

1969 Las clases sociales en las sociedades agrarias, México.

TORRES Quintero, J.

1913 La instrucción rudimentaria en la República Mexicana, México.

Traven B.

Gobierno, México.

La rebelión de los colgados, México.

WEBER, A.

1974 Diagnóstica y praxis de la educación, Tuxtla Gutiérrez, Chiapas. 